九州大学学術情報リポジトリ

Kyushu University Institutional Repository

\title{
Biological Control of the Bacterial Wilt of Tomato with Antibiotic-Producing Strains of Pseudomonas glumae
}

Furuya, Naruto

Laboratory of Plant Pathology, Faculty of Agriculture, Kyushu University

Matsuyama, Nobuaki

Laboratory of Plant Pathology, Faculty of Agriculture, Kyushu University

https://doi.org/10.5109/24007

出版情報：九州大学大学院農学研究院紀要. 37 (2)，pp.159-171，1992-12. Kyushu University バージョン：

権利関係 : 


\title{
Biological Control of the Bacterial W ilt of Tomato with Antibiotic-Producing Strains of Pseudomonas glumae
}

\author{
N aruto F uruya and Nobuaki M atsuyama \\ Laboratory of Plant Pathology, Faculty of Agriculture, \\ Kyushu University 46-01, Fukuoka 812, Japan
}

(Received July 21, 1992)

\begin{abstract}
Pretreatment of the roots of tomato seedlings with the suspension of antibiotic productive strains of Pseudomonas glumae suppressed the severity of wilt incited by challenge inoculation with P.solancearum. The disease suppression was positively correlated with length of dipping time and concentration of the bacterial suspension used for pretreatment. Dipping of the roots of tomato seedlings into the bacterial suspension of ca. $10^{10} \mathrm{cfu} / \mathrm{ml}$ for $24 \mathrm{~h}$ showed highest suppressiveness. The pretreatment of tomato roots with nonantibiotic -producing strain or heat-killed cells of $\mathbf{P}$. glumae also showed protection, suggesting that some mechanisms other than antibiotic productivity were involved in the suppression of the disease. When the roots of tomato seedlings were treated with lipopolysaccharide (LPS) or extracellular polysaccharide (EPS) obtained from P. glumae before inoculation with P. solanacearum, the disease suppression was remarkable. Especially, disease occurrence was suppressed significantly by application of EPS solution. This result indicated that EPS could be involved in the mechanisms of disease suppression.
\end{abstract}

\section{INTRODUCTION}

Bacterial wilt caused by Pseudomonas solanacearum E. F. Smith has been reported in virtually all solanaceous plant producing regions of the world and considered to be the most serious disease (Kelman, 1953; Buddenhagen and Kelman, 1964). At present, various measures such as cultivation of resistant varieties (Matsuda, 1977), crop rotation every other year, and soil disinfection by chemical application have been recommended to control this disease. However resistant cultivars are not immune and there has been some damage during the harvest period. Soil fumigants also have unfavorable effects on environmental factors. As a result none of these procedures is sufficiently effective. Some other effective methods may be developed in the future.

In nature, there are many species of antagonistic micro-organisms living in close contact with other micro-organisms, plants and so on. These antagonistic microorganisms by antibiosis, competition and exploitation, control the population of other micro-organisms including plant pathogenic ones. The use of this phenomenon i.e. biological control, may possibly become an ideal disease control method (Cook and Baker, 1983).

Since successful application of the bacteriocin productive strain 84 of Agrobacterium radiobacter against crown gall of stone fruits (Kerr, 1972 and 1974), the studies have emphasized biological methods to control bacterial diseases of plants, and a number of attempts to control bacterial diseases with antibiotic-producing strains have been made.

Chen et al. (1981 and 1984) reported the efficacy of using an avirulent bacteriocin 
-producing strain of P.solanacearum on the control of bacterial wilt of tobacco. Tanaka et al. (1990) also showed that tobacco plants were protected from bacterial wilt with an avirulent strain M4S of $\boldsymbol{P}$. solanacearum and its bacteriophages. Moreover, Hara and Ono (1991) reported the possibility of biological control on bacterial wilt of tobacco by dipping the root system of seedlings in suspension of a weaklyvirulent bacteriocin-producing strain of $\boldsymbol{P}$. solanacearum prior to transplanting. They concluded that further study was necessary to clarify the mechanism of protection from bacterial wilt and to develop superior strains which would provide effective control.

In general, Pseudomonas spp. are well-documented as effective biological control agents of plant diseases caused by soil borne fungi and bacteria (Weller, 1988).

The authors (1986) previously demonstrated that strains of $\boldsymbol{P}$. glumae Kurita et Tabei, the causal bacterium of grain rot of rice, produced antibacterial substances showing a wide activity spectrum against plant pathogenic bacteria including $\boldsymbol{P}$. solanacearum. These findings led us to this current study on the application of $\boldsymbol{P}$. glumae for the biological control of bacterial disease of plants. This investigation focused on the efficacy of $\boldsymbol{P}$. glumae strains on the protection of tomato seedlings from the infection by $P$. solanacearum under controlled environmental conditions, and its mechanisms.

\section{MATERIALS AND METHODS}

\section{Pseudomonas glumae}

Six strains of $\boldsymbol{P}$. glumae shown in Table 1 were used in this experiment. These strains were cultured on slants of PSA medium (potato $(300 \mathrm{~g})$ decoction 1 liter, $2 \mathrm{~g} \mathrm{Na}$, $\mathrm{HPO}_{4} \cdot 12 \mathrm{H}_{2} \mathrm{O}, 0.5 \mathrm{~g} \mathrm{Ca}\left(\mathrm{NO}_{3}\right)_{2} \cdot 4 \mathrm{H}_{2} \mathrm{O}, 5 \mathrm{~g}$ peptone, $15 \mathrm{~g}$ sucrose, $15 \mathrm{~g}$ agar, $\left.\mathrm{pH} 7.0\right)$ at 30 " $\mathrm{C}$ for 2 to 3 days, suspended in sterile distilled water at a concentration of ca. $10^{7} \mathrm{cfu} /$ $\mathrm{ml}$ in test tubes, and preserved at $22-25^{\circ} \mathrm{C}$ during the experiment. For long term preservation, the bacteria were lyophilized with PS broth and kept at $4^{\circ} \mathrm{C}$.

The bacterial cells were initially grown on PSA slants at $30^{\circ} \mathrm{C}$ for $48 \mathrm{~h}$, suspended in $10 \mathrm{ml}$ of sterile distilled water, added to $200 \mathrm{ml}$ of PS broth in a Sakaguchi flask,

Table 1. Bacterial strains used in this experiment.

\begin{tabular}{|c|c|c|c|}
\hline $\begin{array}{l}\text { Pseudomonas } \\
\text { Species }\end{array}$ & Strain & Isolated from & $\begin{array}{l}\text { Supplied from } \\
\text { or isolated at }\end{array}$ \\
\hline \multirow{6}{*}{ P. glumae } & YN7825 & Oryza sativa & NIAES"” \\
\hline & 750 & ) & $n$ \\
\hline & 752 & ) & Jง \\
\hline & 805 & n & jง \\
\hline & $\mathrm{P} 1-22-4$ & $\eta$ & $n$ \\
\hline & Ku8117 & $n$ & $\mathrm{KU}^{\mathrm{bl}}$ \\
\hline P. solanacearum & c319 & Nicotiana tobacum & $\mathrm{KTES}^{\mathrm{c})}$ \\
\hline
\end{tabular}

a) National Institute of Agro-Environmental Sciences.

b) Kyushu University.

c) Kagoshima Tobacco Experimental Station. 
and shaken at $30^{\circ} \mathrm{C}$ for $48 \mathrm{~h}$. The bacterium was harvested by centrifugation at $6,000 \mathrm{x}$ $\mathrm{g}$ for $20 \mathrm{~min}$, and resuspended in sterile distilled water at a concentration of ca. $10^{10}$ $\mathrm{cfu} / \mathrm{ml}$. The suspension was diluted 10 and 100 times just before use. Viable cells were counted by plating on the PSA medium. Bacterial suspensions thus prepared were used for protecting tomato seedlings from infection with $P$. solanacearum.

\section{Pseudomonas solanacearum}

P. solanacearum strain C319 was maintained in sterile distilled water at $25^{-} 27^{\circ} \mathrm{C}$. Stock suspension was spread on TTC medium (Kelman, 1954) (10g peptone, $1 \mathrm{~g}$ casein hydrolysate (Difco), $5 \mathrm{~g}$ glucose, $17 \mathrm{~g}$ agar, $0.05 \mathrm{mg}$ triphenyl tetrazolium chloride, distilled water 1 liter), and the plates were incubated at $30^{\circ} \mathrm{C}$ for $48 \mathrm{~h}$ in order to select virulent colonies. Typical virulent colonies were isolated and grown in PS broth on a rotary shaker at $30^{\circ} \mathrm{C}$ for $48 \mathrm{~h}$. Cells were harvested by centrifugation at $6,500 \mathbf{x ~} \mathrm{g}$ for $20 \mathrm{~min}$ and resuspended in sterile distilled water to produce concentrations of ca. $10^{8}$, $10^{9}$ and $10^{10} \mathrm{cfu} / \mathrm{ml}$ to be used as inoculum. Viable cells were counted by the plating method on TTC medium. When the inoculum concentration was lower than $10^{8} \mathrm{cfu} / \mathrm{ml}$, the disease symptom did not appear clearly (data not shown).

\section{Induction of non-antibiotic-producing mutants of $P$. glumae by NTG treat- ment.}

A wild strain of $\boldsymbol{P}$. glumae, 750, was cultured on the YPDA medium containing streptomycin sulfate $(500 \mu \mathrm{g} / \mathrm{ml})$ to obtain streptomycin resistant (SR) mutants. The streptomycin resistant parental strain, $750-\mathrm{SR}$, thus obtained was grown in YPD broth under shaking conditions at $30^{\circ} \mathrm{C}$ for $24 \mathrm{~h}$. The bacterial cells were washed twice in sterile phosphate buffer $(0.067 \mathrm{M}, \mathrm{pH} 7.0)$ by centrifugation. The final pellet was resuspended to be the concentration of ca. $10^{7} \mathrm{cfu} / \mathrm{ml}$, which was treated with $N$ methyl-N-nitro-N-nitroso-guanidine (NTG) at the concentration of $50 \mu \mathrm{g} / \mathrm{ml}$ in the same buffer at $30^{\circ} \mathrm{C}$ for $20 \mathrm{~min}$. After treatment, cells were washed twice in the same buffer to remove NTG. A part of the bacterial suspension was transferred to YPD broth and incubated overnight to multiply surviving cells. The culture was then diluted, spread on YPDA plates containing streptomycin sulfate $(500 \mu \mathrm{g} / \mathrm{ml})$ and incubated for 3 to 4 days at $30^{\circ} \mathrm{C}$. Single colony was isolated and each isolate was measured for antibiotic activity by the plating chloroform method (Chen et al., 1981; Wakimoto et al., 1986) using various media containing $\boldsymbol{P}$. solanacearum as an indicator. Thus, a streptomycin resistant and non--antibiotic-productive strain, 750-SR-NP, was obtained.

\section{Heat-killed cells of $P$. glumae}

The bacterial cells of $\boldsymbol{P}$. glumae strain 750 grown on the slant of PSA medium at $30^{\circ} \mathrm{C}$ for $48 \mathrm{~h}$ were suspended in sterile distilled water (conc. ca. $10^{10}$ cell $/ \mathrm{ml}$ ). The suspension was incubated at $100^{\circ} \mathrm{C}$ for $10 \mathrm{~min}$ in a water bath and used to test its suppressiveness to the tomato wilt.

\section{Lipopolysaccharide (LPS) extract}

For phenol extraction, $5 \mathrm{~g}$ of dry bacterial cells was suspended in $100 \mathrm{ml}$ of distilled water at $65^{\circ} \mathrm{C}$ and emulsified with $100 \mathrm{ml}$ of warm $\left(65^{\circ} \mathrm{C}\right) 88 \%$ phenol. The 
emulsion was stirred frequently for $30 \mathrm{~min}$ and then cooled in an ice bath. The cooled solution was centrifuged for $30 \mathrm{~min}$ at $10,000 \times \mathbf{~ g}$. During centrifugation, the emulsion separated into three phases: an aqueous phase on the top, a precipitate at the interface and the phenol phase at the bottom of the tube. The aqueous phase was collected; the precipitate and phenol phases were extracted again with $100 \mathrm{ml}$ of distilled water at $65^{\circ} \mathrm{C}$. After centrifugation, the aqueous phase was collected and combined with the first extract. After dialysis against distilled water for $48 \mathrm{~h}$, the volume of extract was reduced to one fourth the original volume by evaporation under vacuum at $50^{\circ} \mathrm{C}$. Saturated sodium acetate had to be added $(1 \mathrm{ml} / 100 \mathrm{ml})$ to the same preparations to precipitate lipopolysaccharide. The precipitate was collected by centrifugation, dissolved in $25 \mathrm{ml}$ of distilled water, and precipitated again by the addition of six volumes of cold $95 \%$ ethanol. The ethanol precipitate was collected by centrifugation, washed with ether, and dried under vacuum. The preparation of LPS was dissolved in distilled water at 10,5 and $2.5 \mathrm{mg} / \mathrm{ml}$, and used for testing its suppressiveness to tomato wilt.

\section{Extracellular polysaccharide (EPS) extract}

Colonies of P.glumae were streaked heavily onto plates of PSA medium. The plates were incubated at $30^{\circ} \mathrm{C}$ for 3 days; the surface growth was scraped off into 40 $\mathrm{ml}$ of sterile distilled water and the mixture was stirred until uniform. The suspension was centrifuged at $20,000 \mathbf{X} \mathbf{g}$ for $1 \mathrm{~h}$, and the precipitate, containing mainly bacterial cells, was discarded. The supernatant fluid was recentrifuged for $2 \mathrm{~h}$, the precipitate was discarded, and three volume of cold $95 \%$ ethanol was added slowly with stirring to the supernatant fraction. The precipitate which formed was recovered by centrifugation at $3,000 \times \mathbf{~ g}$ for $30 \mathrm{~min}$, washed twice with $95 \%$ and once with absolute ethanol, and finally dried under vacuum. Samples requiring further purification were dissolved in a $0.1 \mathrm{M}$ tris (hydroxymethyl) aminomethane (Tris) buffer, pH 7.4 at $5 \mathrm{mg}$ / $\mathrm{ml}$. A 1.O-mg amount of Pronase per $\mathrm{ml}$ of buffer was added, and incubation was carried out at $37^{\circ} \mathrm{C}$ for $48 \mathrm{~h}$. The digest was then dialyzed for $17 \mathrm{~h}$ against two changes of 40 volumes of distilled water. The extracellular polysaccharide (EPS) was precipitated with three volumes of $95 \%$ ethanol as above, and dried. The preparation of EPS was dissolved in distilled water at 10,5 and $2.5 \mathrm{mg} / \mathrm{ml}$, and used to test its suppressiveness to tomato wilt.

\section{Tomato plants}

To evaluate the suppressiveness of P. glumae cells to bacterial wilt of tomato, the seeds of the Japanese domestic tomato cultivar 'Toko' were used. The seeds were disinfected by being dipped in a solution of 3\% sodium hypochlorite (Antiformin) at room temperature for $15 \mathrm{~min}$, rinsed with tap water, sown on the autoclaved soil in pots $10 \mathrm{~cm}$ in diameter, and incubated in a plant-growth chamber at $30^{\circ} \mathrm{C}$. Two weeks later, plants $10 \mathrm{~cm}$ in height were used.

\section{Pot assay for bacterial wilt suppression}

After pulling out the tomato seedlings, the roots were rinsed with tap water and dipped in a suspension of $P$. glumae (conc. ca. $10^{8}, 10^{9}$ and $10^{10} \mathrm{cfu} / \mathrm{ml}$ ) for periods from $10 \mathrm{~min}$ to $24 \mathrm{~h}$ (pretreatment). The roots thus treated were then dipped in P.solanacear$u m$ suspension (conc. ca. $10^{8}, 10^{9}$ and $10^{10} \mathrm{cfu} / \mathrm{ml}$ ) for $10 \mathrm{~min}$ (post-inoculation). Each 
plant thus treated was transplanted in a plastic pot $(6 \mathrm{X} 6 \mathrm{X} 4.5 \mathrm{~cm})$ containing heat sterilized artificial soil (Kumiai). The plants were grown in a plant-growth chamber at $30^{\circ} \mathrm{C}$. The soil in the pots was kept constantly under wet conditions. The disease severity was recorded at 5-day intervals using the following index: 0 ; no wilt, 1; 1-50\% of leaves wilted, 2; more than $50 \%$ of leaves wilted, 3; entire plant wilted or dead.

\section{M onitoring the population of $P$.glumae and $P$. solanacearum in/on the roots of tomato seedlings}

Tomato roots were dipped in a suspension of $P$. glumae $\left(\right.$ conc. $\left.7.0 \times 10^{9} \mathrm{cfu} / \mathrm{ml}\right)$ or distilled water as a control for $24 \mathrm{~h}$, followed by P. solanacearum (conc. $1.0 \times 10^{10} \mathrm{cfu}$ / $\mathrm{ml}$ ) for $10 \mathrm{~min}$ before transplanting. The treated tomato plants were removed from pots with roots 5, 10 and 15 days after transplanting. Each root sample was shaken in $500 \mathrm{ml}$ of sterile distilled water, weighed and ground in $10 \mathrm{ml}$ of sterile distilled water with a sterile glass rod to permit the release of bacteria from the tissue. Population of $P$. glumae and P. solancearum in/on root was determined using a dilution-platecounting on the S-PG medium (Tsushima et al., 1986) and TTC medium (Kelman, 1954), respectively.

\section{RESULTS}

\section{Protection efficacy shown by $P$. glumae}

Pretreatment with P.glumae showed a significantly lower incidence and severity of wilt, compared with the untreated control. However, the suppresiveness of $P$. glumae to bacterial wilt varied depending upon the duration of the dipping for pretreatment of tomato seedlings. The suppression was slight when seedlings were dipped in a bacterial suspension of $\mathbf{P}$. glumae for $10 \mathrm{~min}$, while it increased in parallel with the duration of dipping. When the seedlings were dipped for 12 or $24 \mathrm{hr}$, the control was marked (Fig. 1). The suppressive effect also varied depending upon bacterial concentrations in both pretreatment and post-inoculation. The effect was the highest at ca. $10^{10}$ $\mathrm{cfu} / \mathrm{ml}$ of $\mathbf{P}$. glumae, while it decreased at $10^{8}$ and $10^{9} \mathrm{cfu} / \mathrm{ml}$. When the inoculum concentration was ca. $10^{8} \mathrm{cfu} / \mathrm{ml}$, the higher suppressive effect was obtained than for $10^{10} \mathrm{cfu} / \mathrm{ml}$ (Fig. 2). Although P. glumae strains Ku8117, 805, 752, Pl-22-4 and YN7825 showed a different degree of antibiosis in vitro, they did not show any significant variation in disease suppressiveness (Fig. 3). The non-antibiotic-producing strain (750 -SR-NP) also suppressed disease to the same level as that shown by the antibioticproducing wild strain (750) (Fig. 4). Furthermore, the heat-killed cells suspension of $P$. glumae $\mathbf{7 5 0}$ also manifested suppresiveness similar to that of living bacteria (Fig. 5).

\section{Effect of LPS and EPS from $P$. glumae on the protection of tomato from bacterial wilt}

As shown in Table 2, tomato plants treated with LPS or EPS showed a more significant decrease in the severity of the disease than the water-treated control 5 days after inoculation. However the effectiveness of LPS decreased with the lapse of time. There was no significant reduction in the severity of disease in tomato plants treated with LPS compared with the water-treated control at 30 days after challenge-inoculation. In contrast, the disease severity of tomato seedlings treated with EPS was 
significantly reduced during the 30-days observation period.

\section{Population of $\boldsymbol{P}$.glumae and $\boldsymbol{P}$. solanacearum in/on root}

Colonization of $P$. glumae and P. solanacearum in/on root is shown in Fig. 6. The population of $P$. glumae was ca. $10^{8} \mathrm{cfu} / \mathrm{g}$ of fresh weight of root after the treatment with $P$. glumae (conc. ca. $10^{10} \mathrm{cfu} / \mathrm{ml}$ ) for $24 \mathrm{~h}$ followed by transplanting in steamsterilized soil. The population of $P$. solanacearum in treated roots and untreated roots was ca. $10^{8}$ and $10^{9} \mathrm{cfu} / \mathrm{g}$ in fresh roots, respectively, immediately after the tomato

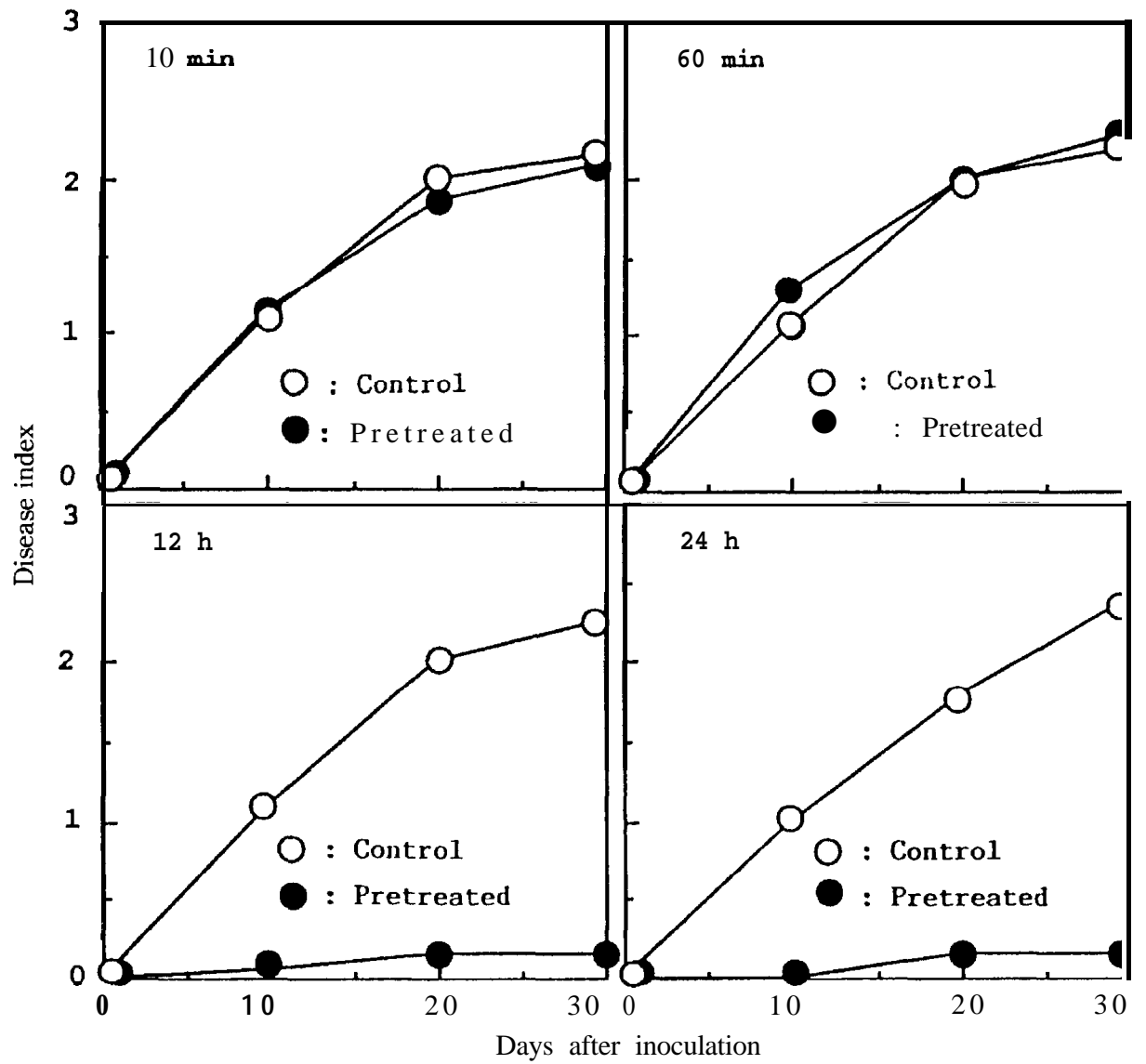

Fig. 1. Protection of tomato seedlings from bacterial wilt by pretreatment with Pseudomonas glumae strain 750. Tomato seedlings were pretreated with a suspension of P.glumae (conc. ca. $10^{10} \mathrm{cfu} / \mathrm{ml}$ ) and challenge-inoculated with P.solanaceanum strain $\mathrm{C} 319$ (con. ca. $10^{8} \mathrm{cfu} / \mathrm{ml}$ ) by dipping their roots just after pretreatment. Sterile distilled water was used instead of a suspension of P. glumae in the case of the check. Disease index based on a scale from 0 , no visible symptom to 3 , entire plant wilted or dead. 
seedlings were dipped in the suspension of $P$. solanacearum (conc. ca. $10^{10} \mathrm{cfu} / \mathrm{ml}$ ) for $10 \mathrm{~min}$. Though the population of P.glumae gradually decreased in/on roots, the population of $P$. solanacearum remained constant $\left(10^{7-8} \mathrm{cfu} / \mathrm{g}\right)$ for 15 days after transplanting. The population of $P$. solanacearum in/on roots of untreated plants remained at 10 times higher level than that of the plants treated with P.glumae for 15 days.
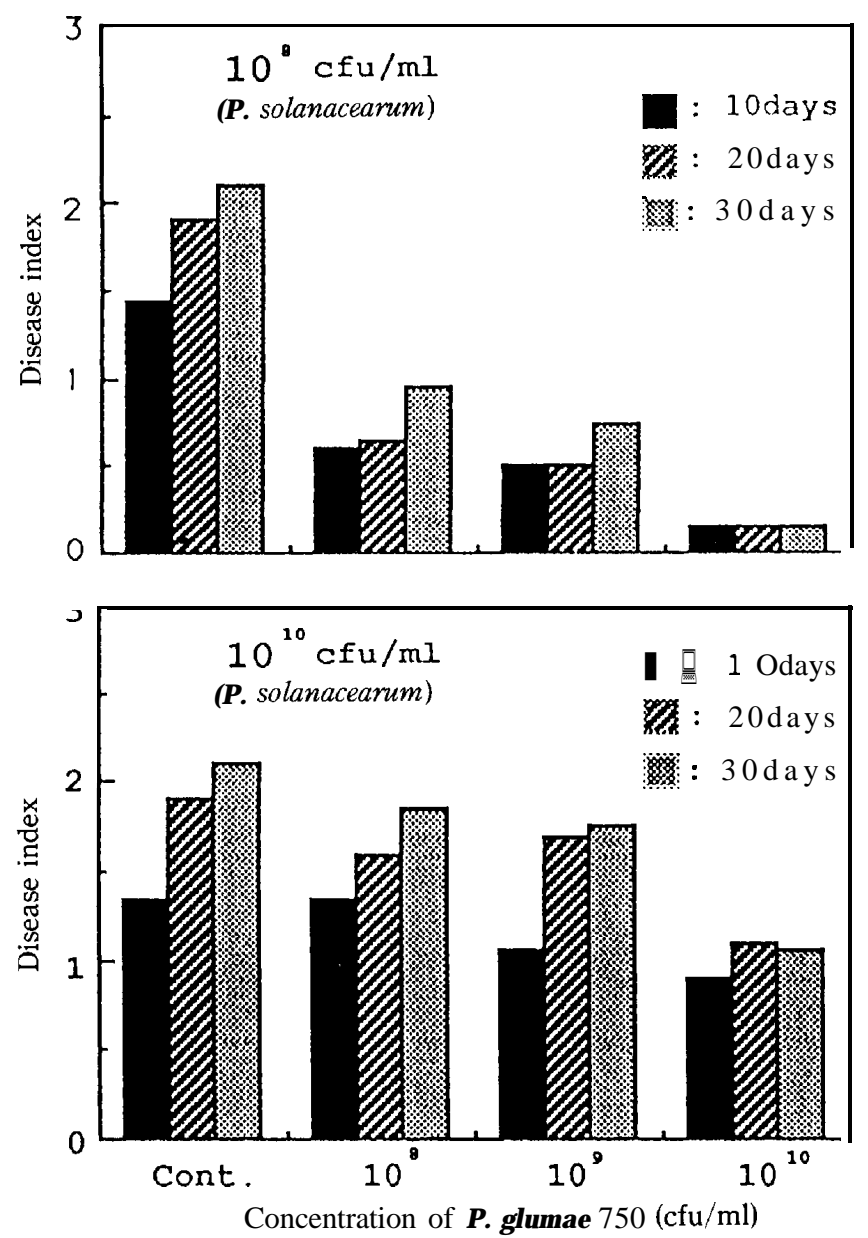

Fig. 2. Suppression of the bacterial seedling rot at different bacterial concentrations of Pseudomonas glumae and P. solanacearum used for pretreatment and inoculation, respectively. Tomato seedlings were pretreated with a suspension of $P$. glumae for 24 $\mathrm{h}$ and inoculated with P. solanacearum strain C319 for 10 min by dipping their roots just after pretreatment. Disease index based on a scale from 0 , no visible symptom to 3 , entire plant wilted or dead. 


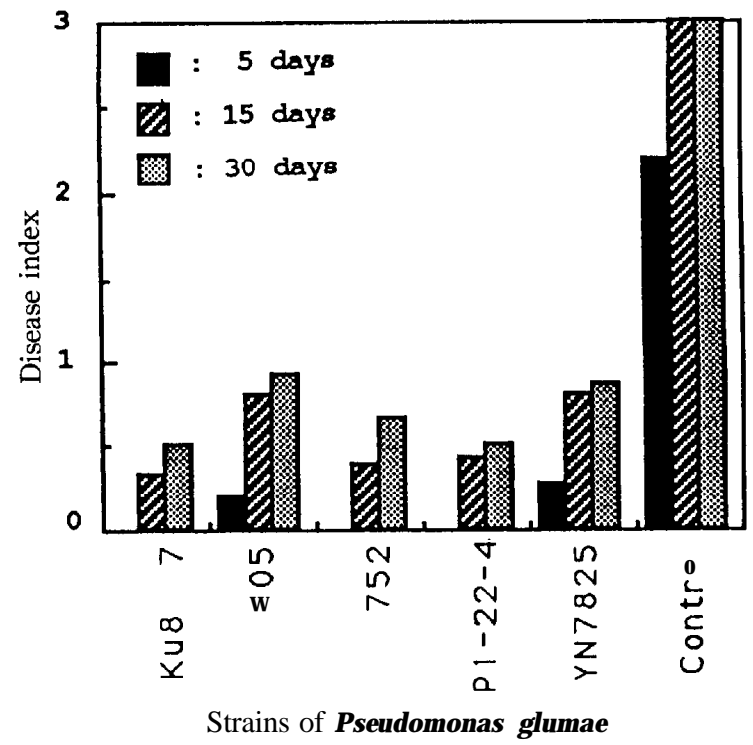

Fig. 3. Comparison of Pseudomonas glumae strains on the protection of tomato seedlings from the bacterial wilt infection. The roots of tomato seedlings were dipped in suspension of $P$. glumae ca. $10^{10} \mathrm{cfu} / \mathrm{ml}$ for $24 \mathrm{~h}$ and then dipped in $\mathbf{P}$. solanacearum suspension (conc. ca. $10^{8} \mathrm{cfu} / \mathrm{ml}$ ) for $10 \mathrm{~min}$. Disease index based on a scale from 0 , no visible symptom to 3 , entire plant wilted or dead.

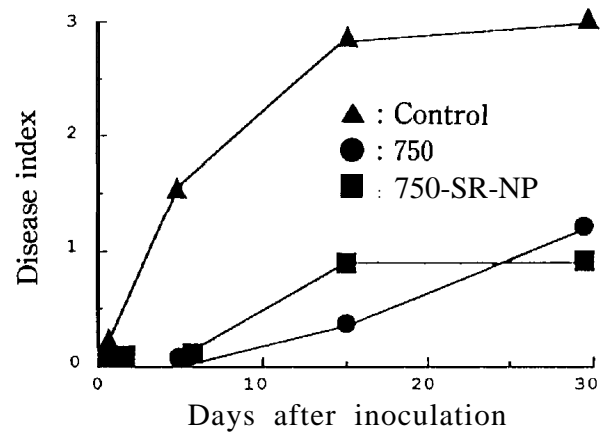

Fig. 4. Effect of non-antibiotic-producing mutant (750-SR-NP) of Pseudomonas glumae on the protection of tomato seedlings from bacterial wilt. The roots of tomato seedlings were dipped in suspension of $\mathbf{P}$. glumae at ca. $10^{10} \mathrm{cfu} / \mathrm{ml}$ for $24 \mathrm{~h}$ and then dipped in P. solanacearum suspension (conc. ca. $10^{8} \mathrm{cfu} / \mathrm{ml}$ ) for $10 \mathrm{~min}$. Disease index based on a scale from 0 , no visible symptom to 3 , entire plant wilted or dead. 


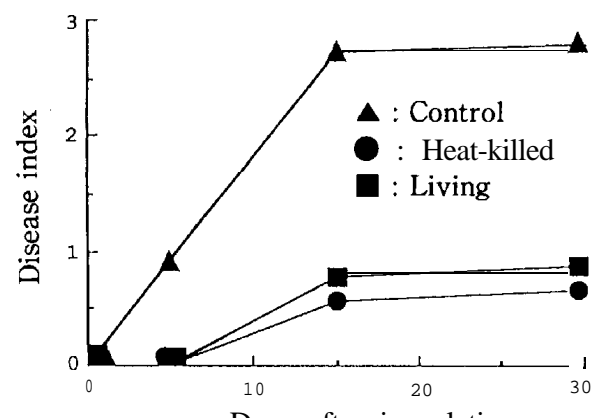

Days after inoculation

Fig. 5. Effect of the heattkilled cells of Pseudomonas glumae $\mathbf{7 5 0}$ on the protection of tomato seedlings from bacterial wilt. The roots of tomato seedlings were dipped in suspension of living bacteria or heattkilled bacteria of P. glumae for $24 \mathrm{~h}$ and then dipped in P. solanacearum suspension (con. ca. $10^{8} \mathrm{cfu} / \mathrm{ml}$ ) for $10 \mathrm{~min}$. Disease index based on a scale from 0 , no visible symptom to 3 , entire plant wilted or dead.

Table 2. Protection of tomato seedlings from bacterial wilt by lipopolysaccharide (LPS) and extracellular polysaccharide (EPS) from Pseudomonas glumae.

\begin{tabular}{|c|c|c|c|}
\hline \multirow{2}{*}{$\begin{array}{l}\text { Concentration of } \\
\text { LPS and EPS (ppm) }\end{array}$} & \multicolumn{3}{|c|}{ Disease index ${ }^{\mathrm{b})}$} \\
\hline & 5 & 15 & 30 days \\
\hline \multicolumn{4}{|l|}{ LPS } \\
\hline 2,500 & $0.13 \mathrm{BC}^{\mathrm{c})}$ & $1.60 \mathrm{AB}$ & $1.60 \mathrm{AB}$ \\
\hline 5,000 & $0.60 \mathrm{~B}$ & $1.40 \mathrm{AB}$ & $1.40 \mathrm{AB}$ \\
\hline 10,000 & $0.13 \mathrm{BC}$ & $1.00 \mathrm{BC}$ & $1.40 \mathrm{AB}$ \\
\hline \multicolumn{4}{|l|}{ EPS } \\
\hline 2,500 & $0.00 c$ & $1.00 \mathrm{BC}$ & $1.00 \mathrm{BC}$ \\
\hline 5,000 & $0.13 \mathrm{BC}$ & $0.20 \mathrm{CD}$ & $0.40 \mathrm{C}$ \\
\hline 10,000 & $0.00 c$ & $0.00 \mathrm{D}$ & $0.00 c$ \\
\hline Water control & $1.20 \mathrm{~A}$ & $2.20 \mathrm{~A}$ & $2.20 \mathrm{~A}$ \\
\hline
\end{tabular}

a) Tomato seedlings were pretreated with a suspension of LPS or EPS at each concentration and inoculated with P. solanacearum strain C319 (ca. $10^{10} \mathrm{cfu} / \mathrm{ml}, 10$ min) by dipping their roots just after pretreatment.

b) Disease index based on a scale from 0 , no visible symptom to 3 , entire plant wilted or dead.

c) Within columns, means with same letter are not significantly different $(P=0.05)$ according to the Duncan's multiple range test.

\section{DISCUSSION}

Non-pathogenic and bacteriocin productive strains of P.solanacearum have been reported to be applicable for biological control of bacterial wilt of solanaceous plants caused by P.solanacearum (Chen et al., 1984 and 1981; Trigalet, 1990). The mechanism of the suppression of the disease above mentioned was considered to be the inhibition 


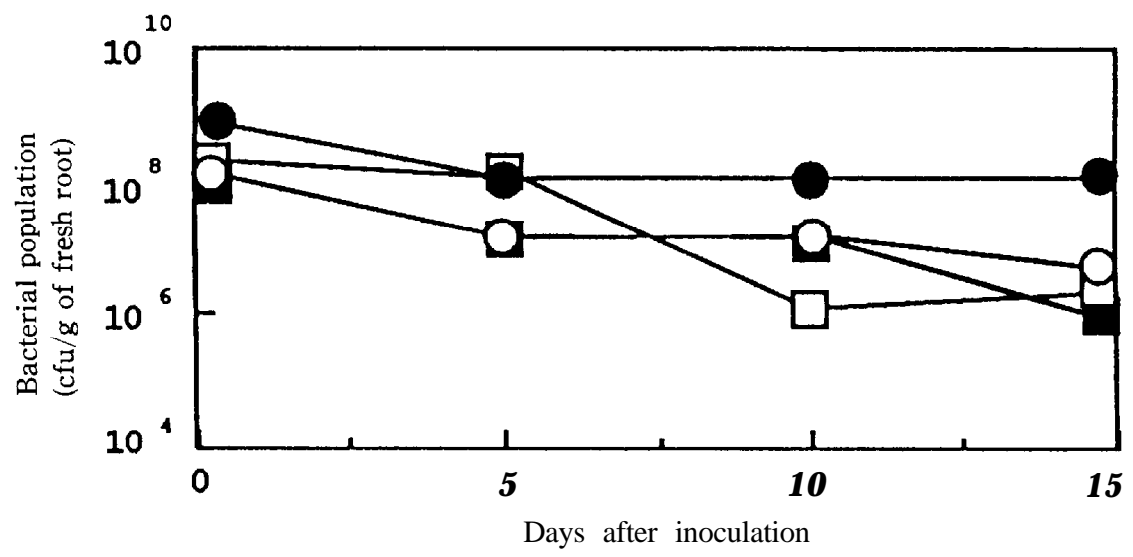

Fig. 6. Growth competition between Pseudomonas glumae and P. solanaceamcm on/in roots of tomato seedlings. Tomato roots were dipped in the suspension of P. glumae $\left(7 \times 10^{9} \mathrm{cfu} / \mathrm{ml}\right)$ for $24 \mathrm{~h}$ and followed by $\mathbf{P}$. solanacearum $\left(1 \times 10^{10} \mathrm{cfu} / \mathrm{ml}\right)$ for $10 \mathrm{~min}$.

- :P. solanaceamcm in mixed culture $\mathbf{\square}: \mathbf{P}$. glumae in mixed culture

0: P. solanacearum in single culture $\square$ : P. glumae in single culture

of the multiplication of pathogenic bacteria by bacteriocin producing non-pathogenic bacteria, Of the interest, $P$. glumae produced antibiotics which inhibit growth of various plant pathogenic bacteria including P. solanacearum (Wakimoto et al., 1986). All strains of $P$.glumae showed antibiotic activity against P. solanacearum on TTC medium in vitro. This finding led us to the attempt to use P. glumae as a potential agent for biological control of bacterial wilt of tomato. Dipping the roots of tomato seedlings in suspension of P. glumae just before inoculation with P. solanacearum showed marked disease suppression. The efficacy of suppression varied with bacterial concentration used for pretreatment (P. glumae) and post-inoculation (P.solanacear . urn), and the duration of the dipping for pretreatment. The highest suppression was observed when tomato seedlings were treated with P. glumae by dipping at the concentration of $\mathrm{ca} .10^{10} \mathrm{cfu} / \mathrm{ml}$ for $12-24 \mathrm{~h}$. This result suggested that the mechanism of disease suppression could relate with the adhesion of $\mathbf{P}$. glumae to the roots and the induction of resistance, because several hours were needed to express the efficacy for the disease control. The data agreed, in part, with the work of Averre and Kelman (1964) and indicated that the disease severity is related to the ratio of $\mathbf{P}$. solanacearum to $P$. glumae cells in the inoculum solution. In this study with $P$. glumae, the suppression or reduction of disease severity clearly related with the low concentration of $\mathbf{P}$. solanacearum to P. glumae cells. Trigalet et $a l$. (1990) also showed that $\mathrm{Tn}-5$ induced avirulent mutants of P. solanacearum competed with virulent strains in planta, and tomato plants were protected from the bacterial wilt. In this case, the degree of competition increased as the concentration of avirulent strains increased. In general, effectiveness of the control by bacterization is obtained when the concentration of the antagonist is higher than that of the pathogen.

The bacterial strains used in this experiment were those producing antibiotics effective against P. solanacearum in vitro experiment. However, it is not known 
whether the mechanisms of the protective effect were caused by antibiotics produced by $P$.glumae which colonized around tomato roots, or by some other mechanisms such as the protection of tomato roots from the invasion of $P$. solanacearum or by systemic resistance induction by pretreatment with $P$. glumae. Main (1968) pretreated susceptible tobacco cuttings with avirulent mutants of $P$. solanacearum, and observed protection when they were subsequently challenged by virulent bacteria. Kempe and Sequeira (1983) demonstrated that induced resistance through pretreatment with pseudomonads may be involved in the mechanism of suppression of bacterial wilt of potato.

To investigate the mechanisms of disease suppression, a non-antibiotic-producing mutant of $P$. glumae (750-SR-NP) induced by NTG treatment and heat-killed bacterial cells were used. Both non-antibiotic-producing living bacteria and heat-killed bacteria suppressed disease severity like antibiotic producing viable wild strain, as in the case of heat-killed cells of P. solanacearum reported by Tanaka (1983). Therefore, the protective effect was not considered to be caused simply by antibiotics produced by $P$. glumae but that some other complicated mechanisms were involved.

The multiplication of $P$.glumae and $P$. solanacearum under mixed culture on/in roots of tomatoes was compared with that under a single culture. Both bacteria multiplied showing almost the same pattern. This is additional evidence to support the conclusion that the failure of pathogenesis to progress in the plants could not be attributed to the inhibition or elimination of P. solanacearum population in the host by $P$. glumae. Further, no fundamental alteration in the inherent virulence of $P$. solanacearum occurred, since inoculations with pure cultures obtained in reisolations were equal in virulence to the original culture of $P$. solanacearum.

The possibility of disease control using lipopolysaccharide (LPS) or extracellular polysaccharide (EPS) was examined in this study. When the roots of tomato seedlings were treated with LPS or EPS obtained from P. glumae before inoculation with $P$. solanacearum, the disease suppression was evident. In particular, occurrence of disease was suppressed significantly by application of EPS solution. This result indicates that EPS plays an important role in the suppression of bacterial wilt of tomato seedlings through pretreatment with $P$. glumae. It was demonstrated that lipopolysaccharides on bacterial cell wall were responsible for induced-resistance in tobacco leaves (Graham et al., 1977). However, Chen et al., (1984) reported that LPS did not play a major role in protecting tobacco plants treated with avirulent strain from bacterial wilt. Further study should be conducted to clarify the mechanism of protection in detail.

Although tomato plants have been protected by treatment of $P$. glumae, cost efficiency has not been sufficient for commercial use. The present strains of $P$. glumae need to be improved before they can be used effectively for control of bacterial wilt. It may be possible to develop superior strains through selection or genetic methods which would develop high adaptivity, rapid movement and multiplication, and good biocontrol in the rhizoplane and rhizosphere of plants.

Control of bacterial wilt of tobacco, tomato and brown rot of potato with avirulent strains of $P$. solanacearum has been reported on greenhouse and also in a limited field trial. However these control measures have not been reported for commercial production of these plants. Often single biological control measures are less beneficial than those afforded by conventional chemical control, and the use of non-pathogenic strains of $P$. glumae is probably in the same category. An effective means for enhancing 
biological control of bacterial wilt must be developed.

\section{ACKNOWLEDGEMENTS}

The authors are indebted to Mr. S. Agarie, Department of Agronomy in Kyushu University for computing statistical treatment with Duncan's multiple range test.

\section{REFERENCES}

Averre, C.W. III and A. Kelman 1964 Severity of bacterial wilt as influenced by ratio of virulent cells of Pseudomonas solanacearum in inoculum. Phytopathology, 54: 779-783

Buddenhagen, I.W. and A. Kelman 1964 Biological and physical aspects of bacterial wilt caused by Pseudomonas solanacearmm. Ann. Rev. Phytopathol., 2: 203-230

Chen, W.Y., E. Echandi and H.W. Spurr, Jr. 1981 Protection of tobacco plants from bacterial wilt with avirulent bacteriocin-producing strains of Pseudomonas solanacearum. Proc. Fifth Int. Cont. Plant Path. Bact.,Cali., 482-492

Chen, W.Y. and E. Echandi 1984 Effect of avirulent bacteriocin-producing strains of Pseudomonas solanacearum on the control of bacterial wilt of tobacco. Plant Pathology, 33: 245-253

Cook, R.J. and K.F. Baker 1985 The nature and practice of biological control plant pathogens. A m. Phytopathol. Soc., St. Paul, Minn., 539 pp.

Graham, T.L., L. Sequeira and T. Huang 1977 Bacterial lipopolysaccharides as inducers of disease resistance in tobacco. Appl. Environ. Microbiol., 34: 424-432

Hara, H. and K. Ono 1991 Effect of weakly-virulent bacteriocin-producing strain of Pseudomonas solanacearum on the protection of tobacco plant from bacterial wilt. Ann. Phytopath. Soc. Japan, 57: 24-31

Kelman, A. 1953 The bacterial wilt caused by Pseudomonas solanacearum. North Carolina Agr. Expt. Sta. Tech. Bull., 99: 1-194

Kelman, A. 1954 The relationship of pathogenicity of Pseudomonas solanacearum to colony appearance in a tetrazolium medium. Phytopathology, 44: 693-695

Kempe, J. and L. Sequeira 1983 Biological control of bacterial wilt of potatoes: attempts to induce resistance by treating tubers with bacteria. Plant Disease, 67: 499-503

Kerr, A. 1972 Biological control of crown gall:Seed inoculation. J.Appl.Bacteriol., 35: 493-497

Kerr, A., and A. Hatay 1974 Biological control of crown gall through bacteriocin production. Physiol. Plnat Pathol., 4: 37-44

Matsuda, T. 1977 Fundamental studies on the breeding of bacterial wilt resistant varieties in tobacco. Bull. Utsunomiya Tobacco Expt. Sta., 15: 1-90

Main, C.E. 1968 Induced resistance to bacterial wilt in susceptible tobacco cuttings pretreated with avirulent mutants of Pseudomonas solanacearum. Phytopathology, 58: 1058-1059

Tanaka, H. 1983 Protection of tobacco and tomato against root infection of Pseudomonas solanacearum by heat-killed bacterial cells. Ann. Phytopath. Soc. Japan, 49: 66-68

Tanaka, H., H. Negishi and H. Maeda 1990 Control of tobacco bacterial wilt by an avirulent strain of Pseudomonas solanacearum M4S and its bacteriophage. Ann. Phytopath. Soc. Japan, 56: 243-246

Trigalet, A. and D. Trigalet-Demery 1990 Use of avirulent mutants of Pseudomonas solanacearum for the biological control of bacterial wilt of tomato plants. Physiol. Mol. Plant Pathol., 36: 2738

Tsushima, S., S. Wakimoto and S. Mogi 1986 Selective medium for detecting Pseudomonas glumae Kurita et Tabei, the causal bacterium of grain rot of rice. Ann. Phytopath. Soc. Japan, 52: 253-259

Wakimoto, S., K. Hirayae, K. Tsuchiya, Y. Kushima, N. Furuya and N. Matsuyama 1986 Production of antibiotics by plant pathogenic Pseudomonads. Ann. Phytopath. Soc. Japan, 52: 835-842 
Weller, D.M. 1988 Biological control of soilborne plant pathogens in the rhizosphere with bacteria. Ann. Rev. Phytopathol., 26: 379-407 